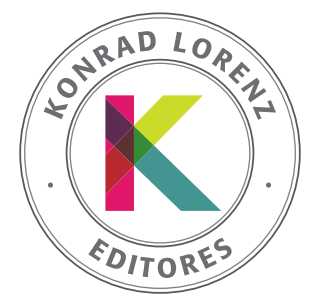

\title{
Relationship between metacognitive skills, gender, and level of schooling in high school students
}

\author{
Duván Ferney Merchán Garzóna , Adriana Patricia Huertas Bustos ${ }^{\mathrm{b} *}$, \\ José Orlando Ugarte Lizarazoc
}

\author{
a Universidad Antonio Nariño, Bogotá, Colombia \\ ${ }^{b}$ Universidad Pedagógica Nacional, Bogotá, Colombia \\ c Universidad de Minessota, Estados Unidos
}

Received 18 October 2019; accepted 21 February 2020

\section{KEYWORDS}

Metacognitive skills, gender,

learning,

level of schooling

\section{PALABRAS CLAVE}

Habilidades metacognitivas, género, aprendizaje, nivel de escolaridad

\begin{abstract}
The objective of this research was to analyse the relationships between metacognitive skills, gender, and level of schooling of high school students from a private school in the city of Bogotá, Colombia. The sample included 319 students from grades 6 to 11. The Metacognitive Awareness Inventory (MAl) was the instrument that allowed determining students' metacognitive skills. This instrument presents two components: cognition and regulation knowledge; consisting of 52 items. The results obtained were analysed through an ANOVA statistical analysis and a Bonferroni contrast. The first analysis concluded that there are no significant differences in metacognitive skills between men and women. On the other hand, the second analysis established differences in the development of metacognitive skills in high school students, favouring sixth grade novices.
\end{abstract}

(c) 2020 Fundación Universitaria Konrad Lorenz. This is an open access article under the CC BYNC-ND license (http://creativecommons.org/licenses/bync-nd/4.0/).

Relación entre las habilidades metacognitivas, el género y el grado en estudiantes de secundaria

Resumen Este trabajo de investigación tuvo como objetivo analizar las relaciones entre las habilidades metacognitivas, el género y el grado de escolaridad en estudiantes de secundaria de un colegio privado de la ciudad de Bogotá-Colombia. La muestra fue de 319 estudiantes que cursaron los grados de sexto a undécimo, el instrumento que permitió determinar las habilidades metacognitivas de los estudiantes fue el Inventario de Conciencia Metacognitiva conocido como MAl, éste instrumento presenta dos componentes el conocimiento de la cognición y de la regulación, consta de 52 ítems. Los resultados obtenidos se analizaron por medio de un análisis estadístico ANOVA y un contraste Bonferroni. El primero, permitió concluir que no existen diferencias significativas en las habilidades metacognitivas entre hombres y mujeres. Por otro lado,

\footnotetext{
* Autor para correspondencia.

Correo electrónico: adripahb@gmail.com
} 
el segundo análisis estableció diferencias en el desarrollo de las habilidades metacognitivas en los estudiantes de secundaria que favorecían a los aprendices de grado sexto.

(c) 2020 Fundación Universitaria Konrad Lorenz. Este es un artículo Open Access bajo la licencia CC BY-NC-ND (http://creativecommons.org/licenses/bync-nd/4.0/).

In recent years, studies related to metacognitive skills are being developed more frequently in educational environments, due to identified relationships between said skills, self-regulation in learning, problem solving, and academic achievement (Memnun \& Akkaya, 2009). Therefore, some researchers consider metacognition to be one of the most prominent learning skills of the 21st century, with a strong relevance in the educational and psychological context (Muawiyah, Yamtinah, \& Indriyanti, 2019).

In this sense, metacognitive skills have been related to different areas of knowledge such as writing, mathematics, information technology, among others, which have concluded that individuals with outstanding skills have superior cognitive performances (Al Shabibi \& Alkharusi, 2018; Roeschl-Heils, Schneider y Van-Kraayenoord, 2003; Sanabria, Ibáñez \& Valencia, 2015). Similarly, Kuiper (2002) asserts that people who are aware of the manner in which they learn achieve better academic performances. She also discusses that metacognition stimulates and fosters reflective thinking, grants responsibility, builds self-confidence in order to make effective decisions and enables the development of critical and creative thinking.

Given that metacognition is a fundamental skill in successful learning, several studies have explored its relationship with other variables, such as gender and level of schooling. In this regard, studies relating metacognition to gender present contradictory results, since some did not find differences between men and women, (Chantharanuwong, Thatthong, Yuenyong \& Thomas, 2012; Hemdan, 2012) whereas other studies conclude that women have greater metacognitive skills compared to men (Akin, 2016; Al-Hilawani, 2001; Ciascai \& Lavinia, 2011). Regarding the level of schooling, research establishes significant differences between the population with different academic levels, where some studies favour higher levels (RoeschlHeils, Schneider \& Van-Kraayenoord, 2003; Van-Kraayenoord, Beinicke, Schlagmüller \& Schneider, 2012; Van-Kraayenoord \& Schneider, 1999) and others the lower levels (Harding, et al., 2019).

Considering the contradictory results described, this research analyses the relationship between metacognitive skills, gender, and level of schooling for a group of 319 high school students from a private school in the city of Bogotá - Colombia; hence, contributing to knowledge in this field of research.

\section{Theoretical Framework}

\section{Metacognition in Learning}

The term metacognition was proposed by Flavell (1976) and defined as the awareness that individuals have of their cognition and the how they regulate their learning. On the other hand, Boekaerts, Pintrich, \& Zeidner (2000) identify three relevant aspects of metacognition: first, the awareness that novices have regarding their academic strengths and weaknesses; second, their knowledge of the cognitive resources used in developing learning tasks; and third, the regulation of their actions in order to optimize learning processes and outcomes.

According to Schraw and Moshman (1995), metacognition has two components: cognition knowledge and regulation knowledge. The first component refers to the people's awareness of their own knowledge or their own cognition in general; this component presents three subcomponents. The first, declarative knowledge refers to awareness of oneself as a novice and of the factors affecting cognition (Flavell, 1976; Kuhn \& Dean, 2004; Paris, Cross, \& Lipson, 1984; Schraw \& Moshman, 1995); the second, procedural knowledge, analyses awareness and knowledge management (Kuhn \& Dean, 2004; Schraw \& Moshman, 1995); and the third, conditional knowledge assesses the ability of knowing how and when to use a learning strategy (Schraw \& Moshman, 1995).

Similarly, the second component presents five subcomponents: (1) Planning - the establishment of learning goals and identification of resources and times to adequately develop educational activities (Brown, 1987; Schraw \& Moshman, 1995), (2) Organization - the identification of the skills and strategies needed to organize learning processes, (3) Monitoring - the supervision of their learning during task development with the purpose of establishing aspects to be improved, (4) Control - the identification of their weaknesses in learning in order to adjust strategies and thus optimize results, (5) Assessment -, the analysis of the effectiveness of implemented strategies and the reflection on the results obtained in a learning episode (Nelson \& Narens, 1990; Schraw \& Denninson, 1994).

Finally, it is possible to conclude that in the educational environment, several studies have addressed the topic of metacognition by considering it as an object of study given that it refers to the conscientious control of cognitive activity (Cera, Mancini, \& Antonietti, 2013; Joseph, 2010; Ku \& Ho, 2010; Lajoie, 2008; Mango, 2010; Pintrich, 2010; Zabel, 2005; Zohar \& Barzilai, 2013).

\section{The importance of Metacognition in learning processes}

Different studies in the field of education highlight the importance of developing metacognitive skills and relate them to academic achievement in different knowledge areas and self-regulation (Doganay \& Demir, 2011; Hernández \& Camargo, 2017; Klimenko \& Alvares, 2009; Mango, 2010; Ozsoy, 2011). In this field of knowledge, some studies which establish relationships between the aforementioned variables stand out. As is the case of Young \& Fry (2008), who analysed the relationship between the metacognitive skills and the academic results of 178 higher education students. Metacognitive skills were determined through MAI and academic achievement was established by the grades obtained at the end of the semester. A correlational analysis found that metacognitive skills are positively related to academic 
achievement; in other words, individuals with greater skills perform better in their learning. It was also concluded among undergraduate and postgraduate students; first, there are no differences in the scores obtained in cognition knowledge, and secondly, there are significant differences in cognition regulation, which could indicate that postgraduate students have greater skills to effectively plan, organize, monitor, control, and assess their learning activities.

Narang and Saini (2013) also identified the impact of metacognition on the academic performance of 240 rural school students. The MAl allowed establishing metacognitive abilities of novices in terms of cognition and regulation knowledge, while academic achievement was established by calculating the average of the novices' grades. The findings led to the inference that most of the students with a high metacognitive level scored above average in terms of academic performance, concluding that the components of metacognition; in other words, cognition knowledge and cognition regulation, significantly contributed to respondents' academic achievement. However, an exception to this finding was observed for girls who exhibited a high metacognition level, but a low academic average, which can probably be explained by the overload of extracurricular responsibilities.

Similarly, Javanmard, Hoshmandja, and Ahmadzade (2012) conducted a descriptive study with the aim of identifying the relationship between self-efficacy, metacognitive strategies, and learning achievement. The research was comprised of 322 students and was developed using the self-efficacy scale, the scale of cognitive and metacognitive strategies, and an academic scale. Based on a statistical study, the results obtained show there is a correlation between metacognitive skills and learning achievement, corroborating that students who use these strategies have a better academic performance.

In conclusion, different studies substantiate the relationship between metacognitive skills and learning achievement; in other words, that students with better academic performance have higher metacognitive skills compared to those with low grades (Rickey \& Stacy, 2000; Young \& Fry, 2008). Also, different studies substantiate that students with low academic performance can implement strategies that improve their metacognitive skills and favour their learning achievements.

\section{Relationship between Metacognition and Gender}

Studies carried out regarding the relationship between gender and metacognitive skills have found contradictory results. On the one hand, some researches have determined a relationship between these variables, but other studies did not identify any relationship whatsoever. In this sense, Akin (2016) developed a study to establish the levels of metacognitive awareness in students of different levels of schooling, to which the scale of metacognitive awareness was applied and correlated to gender. The results indicated that women develop better metacognitive skills compared to men.

What's more, Ciascai and Haiduc (2011) conducted a research aimed at identifying possible relationships between gender and metacognitive skills, with a sample of 91 high school students, using the junior MAl as an analytical tool.
The study's results determined that there is a significant difference in the knowledge cognition category that favours women.

Similarly, Al-Hilawani (2001) conducted a study aimed at examining the metacognitive performance of novices with hearing impairment and normal hearing. The research was carried out with a total sample of 107 students distributed into two groups. The first group was comprised of students with normal hearing (42 men, 45 women) and the second, of students with hearing impairment (13 men and 7 women). The "Metacognitive Awareness" instrument was used to determine the skills in that sense and an ANOVA analysis established a positive correlation between the women's scores and metacognitive skills in people with normal hearing; in other words, the results indicated that women are more aware of their learning.

On the contrary, there are studies that do not identify differences between men and women regarding the development of metacognitive skills. For example, the research carried out by Onat (2012) aimed at determining the metacognitive awareness level of higher education students stands out. The population that took part in the study corresponded to 92 students, who answered the Metacognitive Awareness Scale (MAS) and thus three dimensions of their metacognitive awareness were defined; first, self-awareness; second, metacognitive strategies, and third, assessment. The statistical analyses determined that there is no correlation between gender and the dimensions of the aforementioned instrument.

Similarly, the study proposed by Chantharanuwong et al., (2012) analysed learning environments and their impact on metacognitive development. 1376 students from different primary schools participated in the study. The research applied the Metacognitive Orientation Learning Environment Scale Science (MOLES-S) instrument and an ANOVA analysis revealed that there are no significant differences in the relationship to gender, level of schooling, age, and metacognitive development.

Similarly, in his research, Hemdan (2012) sought to explore the relationship between the theory of mind, metacognition, and self-regulation. The study included a sample of 87 preschool children. The study's methodological development consisted of developing tasks on the theory of mind, metacognitive and self-regulatory activities, which were assessed through a checklist proposed by the researchers. Based on the results, it was possible to evidence that there is no significant difference in the metacognition and self-regulation processes between men and women.

In summary, the studies carried out show that there is no gender consensus regarding metacognitive skills in different levels of schooling. Some studies find that women have better metacognitive skills compared to men (Akin, 2016; Al- Hilawani, 2001; Ciascai \& Lavinia, 2011). On the other hand, studies carried out by Chantharanuwong, et al., (2012), conclude that there is no difference in metacognitive activity between men and women.

\section{Metacognition and Level of Schooling}

In this knowledge area, several studies have explored the relationship between metacognitive skills and level of schooling. The findings are not conclusive, as some re- 
searches indicate that at higher levels of schooling, students are more aware of their knowledge and how they regulate it. On the other hand, other research finds greater metacognitive abilities in lower levels of schooling.

In this sense, Van-Kraayenoord and Schneider (1999) developed an investigation with the objective of analysing the relationships between, (1) reading comprehension, (2) metacognitive knowledge, and (3) memory. The study involved the participation of 140 students, 72 third graders and 68 fourth graders. Researchers used the Knuspels test to determine reading comprehension; the Reading Awareness instrument was used to establish metacognitive knowledge, and finally, the Wiirzburg metamemory test was used to identify memory. Based on the different statistical analyses, it was possible to ascertain that there are significant differences between metacognitive and emotional variables. It was also possible to find a relationship between word coding skills and metacognitive knowledge test performance. Regarding the level of schooling, it was possible to establish significant differences in the metacognitive skills of the third and fourth grade students, favouring those from the higher level of schooling.

In addition, Roeschl-Heils et al., (2003) conducted a research to examine the reading, metacognition, and motivation performance in 7th and 8th graders. The population was comprised of a total of 59 students, 32 seventh graders and 27 eighth graders. The instruments used to develop the study were: (1) a test assessing public reading; (2) a test measuring reading compression and speed, and; (3) a test to assess metacognitive strategies called MSTRAT. A multivariate analysis concluded that the eighth graders scored higher on metacognitive strategies compared to the seventh graders.

Similarly, Van-Kraayenoord et al., (2012) conducted a study aimed at examining metacognitive knowledge, motivation, and reading comprehension in third and fourth graders. The participating population was comprised of 61 third graders and 78 fourth graders. The tool used to establish metacognitive knowledge was the Reading Awareness Index, which determined the regulation knowledge of learners when interpreting texts. The statistical analyses established that there is a correlation between metacognitive processes and level of schooling, favouring fourth graders, given that they performed better on the tests.

Contrary to the results of the studies described above is the work developed by Harding, et al., (2019) with the objective of analysing the possible relationships between self-regulated learning, metacognitive monitoring, and academic performance in students with different levels of schooling. The population participating in the study corresponded to 4232 students from the 5th, 6th, 7th, and 8th grade from 42 public schools. For the study, researchers developed an instrument based on the theory of selfregulated learning (SRL), with the purpose of identifying the characteristics of the students with respect to selfregulation. To analyse the results, an ANOVA test and a Bonferroni were carried out, which allowed establishing significant differences between students' self-regulation processes according to their level of schooling, in turn, determining that students in lower levels of schooling have greater skills to self-regulate their learning and monitor their cognitive skills. This is likely related to the control exercised by primary school teachers in terms of developing learning tasks, which leads students to frequently think about their knowledge and the effectiveness of the strategies they implement when answering assigned activities.

Summarizing, previous researches evidence that there is a relationship between the level of schooling and the development of metacognitive skills, assessed through different strategies; however, there is no consensus that indicates whether higher levels of schooling have better metacognitive skills compared to lower levels of schooling since the study developed by Harding et al., (2019) argues that primary school students have better scores compared to high school students, which contradicts that evidenced by (Roeschl-Heils, et al., 2003; Van-Kraayenoord, et al., 2012; Van-Kraayenoord \& Schneider, 1999).

\section{Method}

The objective of this research was to analyse the relationships between metacognitive skills, gender, and level of schooling in high school students. The methodological aspects of the study are described below.

\section{Participants}

The research involved 319 high school students (154 men and 165 women) from a private school in the city of Bogotá, Colombia. The age of the novices ranged from 12 to 17 years old. Table 1 shows the number of students who participated in the study per level of schooling.

Table 1 Distribution of Students by Level of Schooling

\begin{tabular}{ccccc}
\hline \multirow{2}{*}{$\begin{array}{c}\text { Level of } \\
\text { Schooling }\end{array}$} & $\begin{array}{c}\text { Number of } \\
\text { Students }\end{array}$ & \multicolumn{2}{c}{ Gender } & Percentage (\%) \\
\cline { 3 - 4 } & & Male & Female & \\
\hline Sixth & 42 & 17 & 25 & 13.2 \\
Seventh & 49 & 21 & 28 & 15.4 \\
Eighth & 34 & 19 & 15 & 10.7 \\
Ninth & 85 & 43 & 42 & 26.6 \\
Tenth & 65 & 33 & 32 & 20.4 \\
Eleventh & 44 & 21 & 23 & 13.8 \\
Total & 319 & 154 & 165 & 100.0 \\
\hline
\end{tabular}

\section{Instruments}

\section{Metacognitive Awareness Inventory (MAI)}

The instrument used to establish students' metacognitive skills was the Metacognitive Awareness Inventory proposed by Schraw and Dennison (1994) with a Cronbach's alpha of 0.90. MAl. It is a self-reporting questionnaire that was comprised of 52 items and used a Likert scale with the following statements: (1) Completely disagree, (2) Disagree, (3) Neither disagree or agree, (4) Agree, and (5) Completely agree. The questionnaire has two components: cognition knowledge (17 items) and cognition regulation (35 items). The first component refers to the knowledge that students possess regarding their cognition, and considers three 
subcomponents: declarative knowledge, procedural knowledge, and conditional knowledge. Similarly, the second component refers to the actions the subjects implement which allow them to develop a learning task; it has five subcomponents: planning, organization, monitoring, control, and evaluation.

\section{Procedure}

To develop the project, the school's board was contacted and thus we were able to apply the Metacognitive Awareness Inventory to high school students from 6th, 7th, 8th, 9th, 10th, and 11th grade. Parents were then asked for consent so that their children could participate in the study and they were told the results would be handled confidentially and for research purposes only.

\section{Results}

The Statistical Package for the Social Sciences (SPSS) version 23.0 was used to analyse the data. Initially, data from 340 students was collected, but 21 were excluded since their information was incomplete. Table 2 presents the number of students per gender.

Table 2 Study of Participant's Gender

\begin{tabular}{ccc}
\hline Gender & N & Percentage \% \\
\hline Male & 154 & 48.276 \\
Female & 165 & 51.724 \\
Total & 319 & 100 \\
\hline
\end{tabular}

The instrument's reliability for the chosen population was determined by Cronbach's alpha, which indicated an internal consistency of 0.866 ; these results are consistent with the findings of Huertas, Vesga and Galindo (2014). Table 3 presents Cronbach's alpha for each MAI component.

Table 4 shows the Pearson correlations between the two MAl components. The results indicate there is a strong correlation between the instrument's components (Huertas, Vesga \& Galindo, 2014)

Table 4 Correlations between the two MAl components

\begin{tabular}{ll}
\hline & Cognition Knowledge \\
\hline Regulation Knowledge & $0.611^{* *}$ \\
\hline
\end{tabular}

${ }^{* *}$ Correlation is significant to 0.01 (bilateral).

* Correlation is significant to 0,05 (bilateral)

Table 3 Cronbach's alpha for MAl components
To identify the differences in metacognitive skills between men and women, a one-factor ANOVA was applied. For this test, it is necessary to verify the assumptions of normality and homogeneity. In the case of normality, the Kolmogorov-Smirnov test was used, and the results show that the data have a normal distribution, since the $p$-values in the two MAl components are greater than 0.05, which means that the probability is greater than $5 \%$ (table 5 ).

Table 5 Kolmogorov-Smirnov Test

\begin{tabular}{rcc}
\hline MAI Components & $\mathrm{Z}$ & $\mathrm{P}$ \\
\hline Cognition Knowledge & 1.176 & 0.126 \\
Regulation Knowledge & 1.330 & 0.058 \\
\hline
\end{tabular}

To determine the sample's homogeneity, the Levene test was applied, indicating that the probability $(p)$ is greater in all cases at 0.05 . Therefore, we can say that the variance of the dependent variables in the groups is the same (table 6).

Table 6 Variance Homogeneity Test

\begin{tabular}{ccccc}
\hline MAl Components & Levene Statistic & gl1 & gl2 & P \\
\hline Cognition Knowledge & 0.021 & 1 & 317 & 0.884 \\
Regulation Knowledge & 0.001 & 1 & 317 & 0.980 \\
\hline
\end{tabular}

Once the assumptions were verified, the differences between both genders were found through an ANOVA analysis. The results in table 7 indicate that there are no significant differences between men and women regarding cognition and regulation knowledge; these findings are consistent with several studies conducted in this area of research (Sezgin \& Akkaya, 2009 Chantharanuwong, et al., 2012; Hemdan, 2012; Demirel, Așkınb \& Yağcı, 2015).

Figure 1 shows students' results per level of schooling in cognition and regulation knowledge. To perform a more detailed analysis of the metacognitive skills of students from different levels of schooling, two Bonferroni contrasts were conducted; the first, for cognition knowledge, and the second, for regulation knowledge. The Bonferroni test comparison in table 8 indicates that in cognition knowledge, the sixth graders $(M=3.97, P=0.019<0.05)$ exhibit significant differences compared to the seventh graders, similarly with the eighth graders $(M=3.62, P=0.004<0.05)$, ninth graders $(M=3.62, P=0.001<0.05)$, and eleventh graders $(M=3.73$, $\mathrm{P}=0.022<0.05)$.

\begin{tabular}{ccccccc}
\hline Component & Gender & Mean & Standard Deviation & Minimum & Maximum & Cronbach's alpha \\
\hline $\begin{array}{c}\text { Cognition } \\
\text { Knowledge }\end{array}$ & Male & 3.7044 & 0.44965 & 2.47 & 4.59 & 0.719 \\
\hline $\begin{array}{c}\text { Cognition } \\
\text { Regulation }\end{array}$ & Female & 3.6938 & 0.45395 & 2.53 & 4.94 & 4.49 \\
\hline
\end{tabular}


Table 7 One-factor ANOVA

\begin{tabular}{ccccccc}
\hline MAl Components & & Sum of Squares & gl & Mean Squares & F & Sig. \\
\hline Cognition Knowledge & Inter-groups & 0.009 & 10 & 0.009 & .044 & 0.834 \\
Regulation Knowledge & Inter-groups & 0.025 & 1 & 0.025 & .135 & 0.714 \\
\hline
\end{tabular}

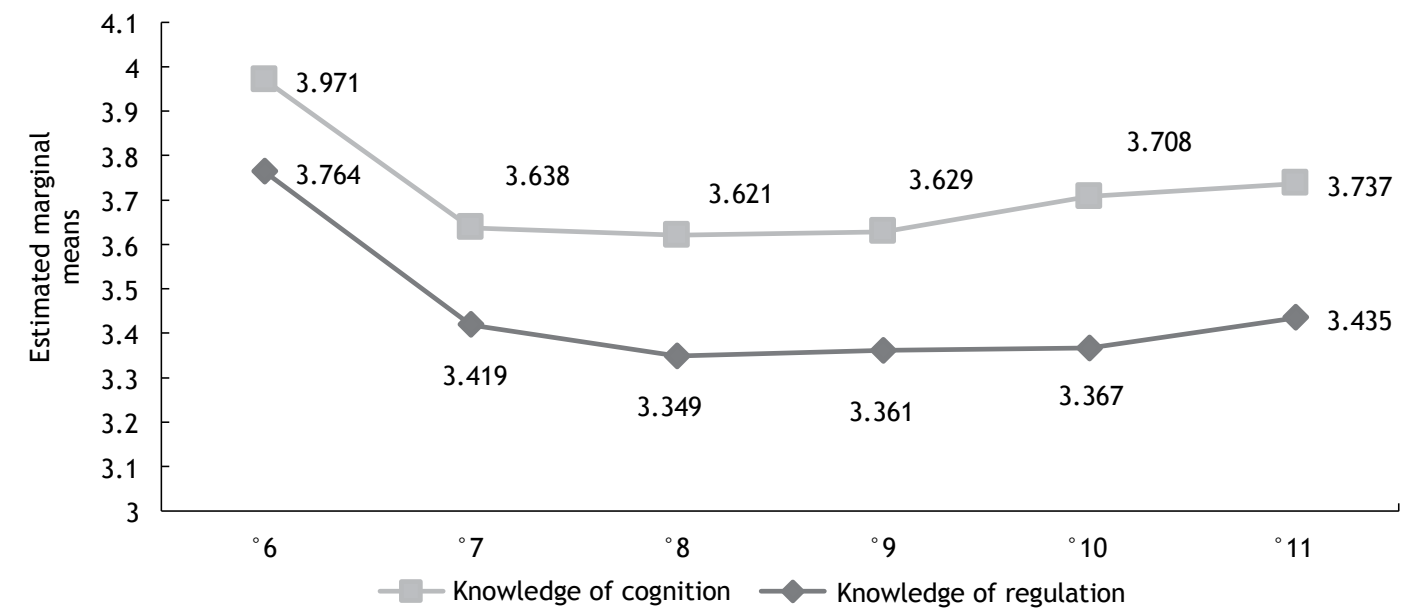

Figure 1. Estimated Marginal Means of Cognition and Regulation Knowledge

Table 8 Bonferroni's Contrast Test for Cognition Knowledge

\begin{tabular}{|c|c|c|c|c|c|c|}
\hline \multirow{2}{*}{ (I) Level of Schooling } & \multirow{2}{*}{ (I) Level of Schooling } & \multirow{2}{*}{ Mean Difference (I-J) } & \multirow{2}{*}{ Standard Error } & \multirow{2}{*}{ Sig. } & \multicolumn{2}{|c|}{ 95\% Confidence Interval } \\
\hline & & & & & Lower Bound & Upper Bound \\
\hline \multirow{5}{*}{${ }^{\circ} 6$} & ${ }^{\circ} 7$ & $0.302^{*}$ & 0.093 & 0.019 & 0.028 & 0.576 \\
\hline & ${ }^{\circ} 8$ & $0.377^{*}$ & 0.101 & 0.004 & 0.077 & 0.678 \\
\hline & ${ }^{\circ} 9$ & $0.343^{*}$ & 0.083 & 0.001 & 0.097 & 0.589 \\
\hline & ${ }^{\circ} 10$ & 0.247 & 0.087 & 0.074 & -0.011 & 0.505 \\
\hline & ${ }^{\circ} 11$ & $0.305^{*}$ & 0.095 & 0.022 & 0.022 & 0.586 \\
\hline \multirow{5}{*}{${ }^{\circ} 7$} & ${ }^{\circ} 6$ & $-0.302^{*}$ & 0.093 & 0.019 & -0.576 & -0.028 \\
\hline & 8 & 0.076 & 0.098 & 1.000 & -0.215 & 0.366 \\
\hline & ${ }^{\circ} 9$ & 0.041 & 0.079 & 1.000 & -0.193 & 0.275 \\
\hline & ${ }^{\circ} 10$ & -0.055 & 0.083 & 1.000 & -0.301 & 0.192 \\
\hline & ${ }^{\circ} 11$ & 0.003 & 0.091 & 1.000 & -0.267 & 0.277 \\
\hline \multirow{5}{*}{${ }^{\circ} 8$} & ${ }^{\circ} 6$ & $-0.377^{*}$ & 0.101 & 0.004 & -0.678 & -0.077 \\
\hline & ${ }^{\circ} 7$ & -0.076 & 0.098 & 1.000 & -0.366 & 0.215 \\
\hline & ${ }^{\circ} 9$ & -0.035 & 0.089 & 1.000 & -0.299 & 0.229 \\
\hline & $\circ 10$ & -0.130 & 0.093 & 1.000 & -0.406 & 0.145 \\
\hline & ${ }^{\circ} 11$ & -0.072 & 0.100 & 1.000 & -0.370 & 0.225 \\
\hline \multirow{5}{*}{${ }^{\circ} 9$} & ${ }^{\circ} 6$ & $-0.343^{*}$ & 0.083 & 0.001 & -0.589 & -0.097 \\
\hline & ${ }^{\circ} 7$ & -0.041 & 0.079 & 1.000 & -0.275 & 0.192 \\
\hline & ${ }^{\circ} 8$ & 0.035 & 0.089 & 1.000 & -0.229 & 0.299 \\
\hline & ${ }^{\circ} 10$ & -0.096 & 0.072 & 1.000 & -0.310 & 0.119 \\
\hline & ${ }^{\circ} 11$ & -0.038 & 0.082 & 1.000 & -0.280 & 0.204 \\
\hline \multirow{5}{*}{${ }^{\circ} 10$} & ${ }^{\circ} 6$ & -0.247 & 0.087 & 0.074 & -0.505 & 0.011 \\
\hline & ${ }^{\circ} 7$ & 0.055 & 0.083 & 1.000 & -0.192 & 0.301 \\
\hline & 8 & 0.130 & 0.093 & 1.000 & -0.145 & 0.406 \\
\hline & ${ }^{\circ} 9$ & 0.096 & 0.073 & 1.000 & -0.119 & 0.310 \\
\hline & ${ }^{\circ} 11$ & 0.057 & 0.086 & 1.000 & -0.197 & 0.312 \\
\hline \multirow{5}{*}{${ }^{\circ} 11$} & ${ }^{\circ} 6$ & -0.305 & 0.095 & 0.022 & -0.586 & -0.024 \\
\hline & ${ }^{\circ} 7$ & -0.003 & 0.091 & 1.000 & -0.274 & 0.267 \\
\hline & ${ }^{\circ} 8$ & 0.073 & 0.100 & 1.000 & -0.225 & 0.370 \\
\hline & ${ }^{\circ} 9$ & 0.038 & 0.082 & 1.000 & -0.204 & 0.280 \\
\hline & ${ }^{\circ} 10$ & -0.057 & 0.086 & 1.000 & -0.312 & 0.197 \\
\hline
\end{tabular}

*The mean difference is significant at the 0.05 level. 
Similarly, Bonferroni's contrast results in table 9 for the regulation knowledge category allow us to establish that once again the sixth graders obtained better scores with respect to the eighth graders $(M=3.348, P=0.003<0.05)$, ninth graders $(M=3.361, P=0.000<0.05)$, tenth graders $(M=3.366, P=0.001<0.05)$, and eleventh graders $(M=3.435$, $\mathrm{P}=0.040<0.05)$. From the results it can be deduced that sixth graders have better metacognitive skills compared to higher levels of schooling in both metacognition components.

\section{Discussion}

Scientific research on learning, cognition, and intervention processes for the purpose of developing skills related to conscious deliberate knowledge, cognition or declarative, procedural, conditional knowledge, and regulation knowledge or strategic deliberate knowledge for planning, organizing, monitoring, controlling, and self-evaluating, have reliable and validated instruments to measure and evaluate the results of the aforementioned aspects. These results are Cronbach's Alfa instrument, which indicated an internal consistency of $\mathbf{0 . 8 6 6}$ for this study, showing very reliable results and findings from a sample and a probably sufficient population of 319 students.
In this same sense, Cronbach's Alpha for each metacognition component indicates that the scale can be used separately in this way, since the results regarding cognition knowledge or consciously knowing how you learn, and cognition regulation knowledge or knowing how cognition is regulated and monitored, are those expected statistically. Undoubtedly, this study and the instruments used pave the way for other researches on effective learning, metacognition, knowledge development, gender, equity, and level of schooling.

Another important conclusive finding is related to Pearson's strong correlations in the MAl between cognition knowledge and cognition regulation, indicating that the instrument has a statistically verifiable internal consistency.

The results show there is no gender consensus regarding metacognitive skills in different levels of schooling, since some studies find women have better metacognitive skills compared to men (Akin, 2016; Al- Hilawani, 2001; Ciascai \& Lavinia, 2011). On the other hand, there is research that concludes that there are no differences in metacognitive activity between men and women (Chantharanuwong, et al., 2012; Demirel, et al.,2015 Hemdan, 2012; Memnun \& Akkaya, 2009, this position gains strength since the one factor analysis of variance (ANOVA) used to evaluate the relationship between metacognitive skills and gender, indicates there are no significant differences between men and women.

Table 9 Bonferroni's Contrast Test for Regulation Knowledge

(I) Level of Schooling (I) Level of Schooling Mean Difference (I-J) Standard Error

\begin{tabular}{|c|c|c|c|c|c|c|}
\hline \multirow{5}{*}{${ }^{\circ} 6$} & ${ }^{\circ} 7$ & 0.214 & 0.088 & 0.229 & -0.045 & 0.474 \\
\hline & ${ }^{\circ} 8$ & $0.363^{*}$ & 0.096 & 0.003 & 0.078 & 0.648 \\
\hline & ${ }^{\circ} 9$ & $0.346^{*}$ & 0.078 & 0.000 & 0.114 & 0.579 \\
\hline & ${ }^{\circ} 10$ & $0.335^{*}$ & 0.083 & 0.001 & 0.091 & 0.579 \\
\hline & ${ }^{\circ} 11$ & $0.272^{*}$ & 0.090 & 0.040 & 0.006 & 0.539 \\
\hline \multirow{5}{*}{${ }^{\circ} 7$} & ${ }^{\circ} 6$ & -0.214 & 0.088 & 0.229 & -0.474 & 0.045 \\
\hline & ${ }^{\circ} 8$ & 0.149 & 0.093 & 1.000 & -0.127 & 0.424 \\
\hline & ${ }^{\circ} 9$ & 0.132 & 0.075 & 1.000 & -0.089 & 0.354 \\
\hline & ${ }^{\circ} 10$ & 0.121 & 0.079 & 1.000 & -0.113 & 0.355 \\
\hline & ${ }^{\circ} 11$ & 0.058 & 0.087 & 1.000 & -0.198 & 0.315 \\
\hline \multirow{5}{*}{${ }^{\circ} 8$} & ${ }^{\circ} 6$ & $-0.363^{*}$ & 0.096 & 0.003 & -0.648 & -0.078 \\
\hline & ${ }^{\circ} 7$ & -0.149 & 0.093 & 1.000 & -0.424 & 0.127 \\
\hline & ${ }^{\circ} 9$ & -0.016 & 0.085 & 1.000 & -0.267 & 0.234 \\
\hline & ${ }^{\circ} 10$ & -0.028 & 0.088 & 1.000 & -0.289 & 0.233 \\
\hline & ${ }^{\circ} 11$ & -0.090 & 0.095 & 1.000 & -0.372 & 0.191 \\
\hline \multirow{5}{*}{${ }^{\circ} 9$} & ${ }^{\circ} 6$ & $-0.346^{*}$ & 0.079 & 0.000 & -0.579 & -0.114 \\
\hline & ${ }^{\circ} 7$ & -0.132 & 0.075 & 1.000 & -0.354 & 0.089 \\
\hline & ${ }^{\circ} 8$ & 0.016 & 0.085 & 1.000 & -0.234 & 0.267 \\
\hline & ${ }^{\circ} 10$ & -0.011 & 0.069 & 1.000 & -0.215 & 0.192 \\
\hline & ${ }^{\circ} 11$ & -0.074 & 0.077 & 1.000 & -0.303 & 0.155 \\
\hline \multirow{5}{*}{${ }^{\circ} 10$} & ${ }^{\circ} 6$ & $-0.335^{*}$ & 0.083 & 0.001 & -0.579 & -0.091 \\
\hline & ${ }^{\circ} 7$ & -0.121 & 0.079 & 1.000 & -0.356 & 0.113 \\
\hline & ${ }^{\circ} 8$ & 0.028 & 0.088 & 1.000 & -0.233 & 0.289 \\
\hline & ${ }^{\circ} 9$ & 0.011 & 0.069 & 1.000 & -0.192 & 0.215 \\
\hline & ${ }^{\circ} 11$ & -0.062 & 0.081 & 1.000 & -0.303 & 0.179 \\
\hline \multirow{5}{*}{${ }^{\circ} 11$} & ${ }^{\circ} 6$ & $-0.272^{*}$ & 0.090 & 0.040 & -0.539 & -0.006 \\
\hline & ${ }^{\circ} 7$ & -0.058 & 0.087 & 1.000 & -0.315 & 0.198 \\
\hline & ${ }^{\circ} 8$ & 0.090 & 0.095 & 1.000 & -0.191 & 0.372 \\
\hline & ${ }^{\circ} 9$ & 0.074 & 0.077 & 1.000 & -0.155 & 0.303 \\
\hline & ${ }^{\circ} 10$ & 0.062 & 0.081 & 1.000 & -0.178 & 0.303 \\
\hline
\end{tabular}

*The mean difference is significant at the 0.05 level. 
Also, the study's findings allow us to conclude that novices exhibit better results in the cognition component compared to the regulation component. The foregoing indicates novices generally focus on cognition and relegate knowledge of factors affecting cognition to second place; in other words, learning regulation processes.

On the other hand, the BSE (Bonferroni significant difference) multiple comparisons test allows us to contrast the means of the MAI components with the levels of schooling of the study's participants. Therefore, it is possible to deduce that sixth graders have higher scores in the cognition knowledge category compared to seventh, eighth, ninth and eleventh grade novices.

Similarly, in regulation knowledge, the results show that sixth graders obtained better scores compared to those in higher levels of schooling. The foregoing allows us to conclude that first-year high school students have greater metacognitive skills compared to students in higher levels of schooling, which is consistent with the study conducted by Harding, et al., (2019), which established that primary school students have better skills compared to high school students.

Under this perspective, a more in-depth approach to the factors influencing the noticeably improved learning of sixth grade women and men is needed, other than that, they are novices at the initial level of high school, since other studies perceived eighth graders to be better readers and it was definitely due to knowledge intervention processes that students have about their own knowledge and the skills developed in regards to regulating their learning tasks.

A significant conclusion, as a positive and future recommendation, is to communicate to the community of teachers, managers, and above all to students with training processes in educational institutions, the fact that it is intimately linked to the existing relationship between students with successful academic results and their knowledge regarding their declarative, procedural, and conditional knowledge learning, and knowledge in terms of self-regulation as the skills to consciously plan, organize, monitor, control, and evaluate the knowledge learned or the task to be developed. In other words, the students who exhibit better academic performance have higher metacognitive abilities compared to students with low grades. On the other hand, and just as important, different studies evidence that subjects with low academic performance can implement strategies that improve their metacognitive skills and favour their learning achievements.

A complex and illuminating conclusion about equity in learning, an individual's education, and integral human development within everyone's reach is that children and youth in the early, middle, as well as in the higher levels of secondary education, are under the same condition and opportunity to learn effectively, achieve excellent academic results, and be successful in their educational processes in school and in life. This success in learning and education is possible if managers, teachers, and educational institutions jointly design, implement, and manage with quality, educational intervention processes in students with the central purpose of developing metacognitive skills that yield youth and adults who become, first, strategic novices who know about declarative, procedural, and conditional knowledge; and second, conscientious autonomous novices who plan, organize, monitor, regulate, and self-evaluate their task's process and their knowledge building throughout their life.

\section{Limitations}

One of the study's limitations is related to the instrument called the metacognitive skills inventory known as MAl. Since it is a self-reporting questionnaire, participants tend to answer based on their social and moral prejudices.

\section{Recommendations}

It would be convenient for subsequent studies on metacognitive skills, gender, and level of schooling, to include primary levels of schooling with the purpose of generalizing teacher practices.

\section{References}

Akin, E. (2016). Examining the relation between metacognitive understanding of what is listened to and metacognitive awareness levels of secondary school students. Educational Research and Reviews, 11(7), 390-401.

Al-Shabibi, A., \& Alkharusi, H. (2018). Mathematical problem-solving and metacognitive skills of 5 th grade students as a function of gender and level of academic achievement. Cypriot Journal of Educational Sciences, 13(2), 149-159.

Al-Hilawani, Y. (2001). Examining metacognition in hearing and deaf/hard of hearing students: A comparative study. American Annals of the Deaf, 146(1), 45-50.

Boekaerts, M., Pintrich, P., \& Zeidner, M. (Eds.). (2000). Handbook of self-Regulation. Academic Press.

Brown, A. (1987). Metacognition, executive control, self-regulation, and other mysterious mechanisms. In F. E. Weinert \& R. H. Kluwe (Eds.), Metacognition, Motivation, and Understanding (pp. 65-116). Hillsdale, NJ: Lawrence Erlbaum.

Cera, R., Mancini, M., \& Antonietti, A. (2013). Relationships between Metacognition, Self-efficacy and Self-regulation in Learning. Educational, Cultural and Psychological Studies, 7, 115 - 141. https://doi.org/10.7358/ecps-2013-007-cera

Chantharanuwong, W., Thatthong, K., Yuenyong, C., \& Thomas, G. (2012). Exploring the metacognitive orientation of the science classrooms in a Thai context. Procedia - Social and Behavioral Sciences, 46, 5116-5123. https://doi.org/10.1016/j. sbspro.2012.06.393

Ciascai, L., \& Lavinia, H. (2011). Gender differences in metacognitive skills. A study of the 8 th grade pupils in romania. Procedia-Social and Behavioral Sciences, 29, 396-401. https://doi. org/10.1016/j.sbspro.2011.11.255

Demirel, M., Așkın, I., \& Yağcı, E.(2015). An investigation of teacher candidates' metacognitive skills. Procedia - Social and Behavioral Sciences, 174, 1521-1528, https://doi.org/10.1016/j. sbspro.2015.01.783

Doganay, A. \& Demir, O. (2011). Comparison of the level of using metacognitive strategies during study between high achieving and low achieving prospective teachers. Educational Sciences: Theory \& Practice, 11(4) 2036-2043.

Flavell, J. (1976). Metacognitive aspects of problem solving: The nature of intelligence. Hillsdale: N.J. Erlbaum.

Flavell, J. (1979). Metacognition and cognitive monitoring- A new area of cognitive-developmental inquiry. American Psicology, 34, 906-911.

Harding, S., English, N., Nibali, N., Griffin, P., Graham, L., Alom, B., \& Zhang, Z. (2019). Self-regulated learning as a predictor of mathematics and reading performance: A picture of students in grades 5 to 8. Australian Journal of Education, 63(1), 74-97. https://doi.org/10.1177/0004944119830153 
Hemdan, A.(2012).The relationship between metacognition and self-regulation in young children. Procedia - Social and Behavioral Sciences, 69, 477-486, https://doi.org/10.1016/j.sbspro.2012.11.436

Hernández A., \& Camargo, Á. (2017). Adaptation and validation of self-regulation strategy Inventory-Self-report in university students. Suma Psicologica, 24(1), 9-16. https://doi.org/10.1016/j. sumpsi.2017.02.001

Huertas, A., Vesga, G., \& Galindo, M. (2014). Validación del instrumento "inventario de habilidades metacognitivas (mai)" con estudiantes Colombianos. Paxis 5, 55-74.

Javanmard A., Hoshmandja, M., \& Ahmadzade L. (2013). Investigating the relationship between self-efficacy, cognitive and metacognitive strategies, and academic self-handicapping with academic achievement in male high school students in the tribes of fars province. Journal of Life Science and Biomedicine, 3(1), 27- 34.

Joseph, N. (2010). Metacognition Needed: Teaching Middle and High School Students to Develop Strategic Learning Skill. Heldref Publications, 45(2), 99-103.

Klimenko, O., \& Alvares, J.(2009). Aprender cómo aprendo: La enseñanza de estrategias metacognitivas. Educación y Educadores, 12(2), 11-28.

Ku, K., \& Ho, I. (2010). Metacognitive strategies that enhance critical thinking. Metacognition and Learning, 5(3), 251-267. https://doi.org/10.1007/s11409-010-9060-6

Kuhn, D., \& Dean, D. (2004). Metacognition: A bridge between cognitive psychology and educational practice. Theory into Practice, 43(4), 268-273. https://doi.org/10.1353/tip.2004.0047

Kuiper, R. (2002). Enhancing metacognition through the reflective use of self-regulated learning strategies. Journal of Continuing Education in Nursing, 33(2), 78-87.

Lajoie, S. (2008). Metacognition, Self Regulation, and Self-regulated Learning: A Rose by any other Name?. Educational Psychology Review, 20(4), 469-475. https://doi.org/10.1007/s10648008-9088-1

Magno, C. (2010). The role of metacognitive skills in developing critical thinking. Metacognition and Learning, 5(2), 137-156. https://doi.org/10.1007/s11409-010-9054-4

Demirel, M. Așkın, İ., \& Yağcl, E. (2015) An Investigation of Teacher Candidates' Metacognitive Skills, Procedia - Social and Behavioral Sciences,Volume 174, 2015, 1521-1528. https://doi. org/10.1016/j.sbspro.2015.01.783

Memnun, D. S., \& Akkaya, R. (2009). The levels of metacognitive awareness of primary teacher trainees. Procedia - Social and Behavioral Sciences, 1(1), 1919-1923. https://doi.org/10.1016/j. sbspro.2009.01.337

Muawiyah, D., Yamtinah, S., \& Indriyanti, N. Y. (2019). Modelling testlet instrument in blended learning design to assess students' metacognition in the environmental chemistry course. Paper presented at the Journal of Physics: Conference Series, 1157(4). https://doi.org/10.1088/1742-6596/1157/4/042012

Narang, D., \& Saini, S. (2013). Metacognition and academic performance of rural adolescents. Studies on Home and Community Science, 7(3), 167-175. https://doi.org/10.1080/09737189.2013. 11885409
Nelson, T., \& Narens, L. (1990). Matamemory: A theoretical framework and new findings The Psychology of Learning and Motivation, 26, 125-173.

Onat, M. (2012). Metacognitive awareness of teacher candidates. Procedia - Social and Behavioral Sciences, $46(4529$ - 4533).

Özsoy, G. (2011). An investigation of the relationship between metacognition and mathematics achievement. Asia Pacific Education Review, 12(2), 227-235. https://doi.org/10.1007/ s12564-010-9129-6

Paris, S., Cross, D., \& Lipson, M. (1984). Informed strategies for learning: A program to improve children's reading awareness and comprehension. Journal of Educational Psychology, 76(6), 1239-1252.

Pintrich, P. (2010). The Role of Metacognitive Knowledge in Learning, Teaching, and Assessing. Theory Into Practice, 41(1), 219225. https://doi.org/10.1207/s15430421tip4104_3

Rickey, D., \& Stacy, A.,(2000). The role of metacognition in learing chemistry. Journal of Chemical Education, 77 (7), 915. https://doi.org/10.1021/ed077p915

Roeschl-Heils, A., Schneider, W., \& Van Kraayenoord, C.E. (2003). European Journal of Psychology of Education, 18, 75-86. https://doi.org/10.1007/BF03173605

Sanabria, L., Ibáñez, J., \& Valencia, N. (2015). Barras bravas: Ambiente metacognitivo digital para apoyar el aprendizaje de las matemáticas. Revista Papeles, 7(14), 42-54.

Schraw, G., \& Denninson, S. (1994). Assessing Metacognitive Awareness. Contemporany Educational Physhology, 19, 460-475.

Schraw, G., \& Moshman, D. (1995). Metacognitive theories. Educational Psychology, 7, 351-371.

Van-Kraayenoord, C., \& Schneider, W. (1999). Reading achievement, metacognition, reading self-concept and interest: A study of german students in grades 3 and 4. European Journal of Psychology of Education, 14(3), 305-324. https://doi. org/10.1007/BF03173117

Van-Kraayenoord, C., Beinicke, A., Schlagmuller, M., \& Schneider, W. (2012). Word identification, metacognitive knowledge, motivation and reading comprehension: An Australian study of Grade 3 and 4 pupils. Australian Journal of Language and Literacy, 35(1), 51-68.

Young, A., \& Fry, J. (2008). Metacognitive awareness and academic achievement in college students. Journal of the Scholarship of Teaching and Learning, 8(2), 1-10.

Zabel, S. (2005). Metacognitive strategies in a web-enhanced environment- The effects on achievement in problem-solving for engineering undergraduates. Graduate School Theses and Dissertations.

Zohar, A., \& Barzilai, S. (2013). A review of research on metacognition in science education: current and future directions. Studies in Science Education, 49(2), 121-169. https://doi.org/10 $.1080 / 03057267.2013 .847261$ 